http://dx.doi.org/10.12775/szhf.2015.043

\title{
Paweł Dybel, Granice rozumienia i interpretacji. O hermeneutyce Hansa-Georga Gadamera, Wydawnictwo Universitas, Kraków 2004 r., ss. 483
}

Niewątpliwie dzieło Gadamera można rozpatrywać z wielu perspektyw. Dybel kieruje swą uwagę zasadniczo na to, w jaki sposób niemiecki myśliciel rozpoznaje filozoficzną naturę hermeneutycznego doświadczenia. W nim zaś upatruje pragmatycznej postaci przejawiania się dziejowości fenomenu rozumienia. Dlatego drugą istotną kwestią jest to, w jaki sposób rozumienie miałoby charakteryzować się pre-ontologiczną strukturą.

Autor Prawdy $i$ metody rozpatruje cztery znaczenia rozumienia: jako intelektualne ujmowanie, praktyczną umiejętność, grę zapośredniczoną i porozumiewanie się w języku. Niemieckiego uczonego interesuje przede wszystkim wielość dziejowych wykładni bycia, które „zagadują” nas (das Ansprehen) niemalże na każdym kroku. Zatem: „[...] nie chodzi wyłącznie o to, aby poświadczać bezpośrednio $\mathrm{w}$ mowie wydarzanie się samego bycia, ale aby opisać dziejowy proces tradycji, w którym „historyczna świadomość” odnosi się do różnych świadectw kulturowej przeszłości, wyobcowujących się nieustannie w swym znaczeniu w stosunku do niej” (s. 81).

Hermeneutyka filozoficzna Gadamera stara się jak najbardziej dopasować do „przedmiotu” swych badań, mając równocześnie na uwadze „samorozumienie" podmiotu poznawczego, ale i historyczność doświadczenia fenomenu rozumienia Dlatego możemy powiedzieć, że wymiar indywidualny badacza rozpływa się w dziejowości, współgra z nim. Kluczowy jest tu termin „pojętej ogólności” (s. 149-151) zaczerpnięty z filozofii transcendentalnej Kanta. Jak czytamy: „[...] człowiek zawsze odnosi się »rozumiejąco« do otaczającego go świata, wykładając go w określony sposób [...]" (s. 165). Nie ma rozumienia bez interpretacji. Służy ona m.in. do odnajdywania i nadawania 
sensu. Dybel nawiązuje w tym kontekście do pojęcia „zastosowania” (s. 212). Nie może dziwić więc fakt, że w refleksji Gadamera szczególne miejsce zajmuje filozofia, jako ta, która każe pytać o to, w jaki sposób, to czego dotyczy ta refleksja, wiąże się z ontologiczną strukturą wszelkiej refleksji. Poznanie nauk humanistycznych każdorazowo jest „samopoznaniem”. Jest to dla nas tak istotne, jak dla Gadamera istotne jest poznanie "pre-ontologicznch" struktur doświadczenia. Dlatego takim pojęciom jak: „przesąd”, „tradycja”, „autorytet” niemiecki uczony przypisuje konstytutywną funkcję.

Do przesądów, w przeciwieństwie do filozofów oświecenia, niemiecki hermeneuta odnosi się pozytywnie. Odróżnia on przesądy "prawdziwe” i „fałszywe”, jak czynili to jego poprzednicy. Niemniej jednak, niezależnie od tego, czy mówimy o przesądach prawdziwych czy nie, są one zawsze podstawą rozumienia. W hermeneutyce prawniczej używa się dobrze oddającego tę funkcję pojęcia: „przed-sądu” (das Vor-urteil). Owe „przed-sądy” są kluczowe dla procesu rozumienia (zarówno na poziomie teoretycznym jak i dziejowym). „Dzięki przesądom możemy zrozumieć coś, jako coś” (s. 254). Dybel o ich „pre-ontologicznym” charakterze pisze m.in. tak: „[...] przesądy nie dołączają się do rzekomo niezmiennego rdzenia owych pojęć jako coś dodatkowego i akcydentalnego, ale stanowią nieodłączny warunek ich ukonstytuowania się jako takich" (s. 257-259). Idea ahistorycznego modelu poznania metodycznego została przez Gadamera odrzucona.

Do opisu znaczącej roli tradycji w hermeneutyce Gadamera dochodzimy na drodze krytyki romantycznego ujęcia historii. Dybel wymienia w tym kontekście takich uczonych jak Droysen, Renke czy Dilthey. Co więcej, tak jak u Hegla i Gadamera można znaleźć wiele punktów wspólnych, co do rozumienia historii, tak w przypadku wymienionych myślicieli już nie. U pierwszego tym co ma spajać tradycję jest „duchowa teraźniejszość” rozumiejącego podmiotu wobec tego, co rozumiane. W przypadku drugiego: idea nieskończonego boskiego rozumu. U Diltheya, w końcu, wewnętrzna totalność i nieskończoność ludzkiego ducha. Krytyka zasadniczo dotyczy metafizycznego charakteru tych koncepcji. Przytoczone powyżej odpowiedzi zdaniem Gadamera są nietrafione, ponieważ nie przezwyciężają one relatywizmu, tak często zarzucanego tym ujęciom historii. Za dobrą monetę można uznać to, że Droysen i Renke przypisywali konkretnej rzeczywistości historycznej pozytywny sens (wartość). Ostatecznie romantyczny kult przeszłości nie rozwiązuje powstałych $\mathrm{w}$ jego obrębie licznych aporii i sprzeczności. W Prawdzie $i$ metodzie znajdziemy propozycję wyjścia $\mathrm{z}$ tego impasu. 
Pojęciu tradycji Gadamer przypisuje znaczenie ontologiczne, to znaczy bezpośredni związek z byciem (Heidegger). Dlatego powiedzieliśmy, że pełni ona funkcję konstytutywną. Wyznacza horyzont dziejowy, ale również umożliwia otwarcie się na nowe sposoby rozumienia. Dlatego też: „[...] tradycja nie jest określona wyłącznie przez to, co przeszłe i do niego się nie sprowadza" (s. 294). Konfrontacja badacza ze świadectwami kulturowymi przeszłości nie ogranicza się tylko i wyłącznie do ich odczytywania, ma ona bowiem strukturę dialogiczną. Owe "rzeczy” niosą ze sobą pewne „prawdy”, sensy, które winniśmy odszyfrowywać. W dialogu ze świadectwami kulturowymi przeszłości, choćby dla ich utrwalenia w naszym „samorozumieniu” - dalej zaś w tradycji, istotne jest ich „zachowywanie” (die Bewahrung). Badacz nie jest niewolnikiem tradycji. „Zachowywanie" to czynność rozumu. Widzimy zatem jak bardzo tradycja i przesądy są ważne dla naszego ujmowania świata. Co więcej: „Fenomen zachowywania tradycji stanowi podstawową figurę ludzkiej tożsamości" (s. 306). Przez „stapianie się horyzontów” - rozumiemy „samoróżnicowanie się" podmiotu-rozumienia w perspektywie przedmiotu i jego sensu.

Trzecim pojęciem, które za sprawą Gadamera doczekało się szerokiej rewitalizacji, jest pojęcie autorytetu. Wiąże się z nim podstawowe założenie „doskonałości” (der Vorgriff der Vollkommenehit), to jest doskonałości jedności sensu (wymiar ontologiczny), „prawdy” danej „rzeczy”. Założenie to sprawia, że autorytet, przedstawiane przezeń „prawdy” i sensy mają ogromne znaczenie dla rozumienia innych. „Otwarcie się” na wszystko co inne daje nam wielkie możliwości do rozwoju i pogłębiania wiedzy. Ufność wobec różnych autorytetów nie jest równoznaczna $\mathrm{z}$ bezkrytycznym przyjmowaniem głoszonych przezeń „prawd”: „Autorytet jako inny nie stanowi zagrożenia dla samorozumienia jednostki, ale może je otworzyć na prawdy, które były jej do tej pory całkowicie obce. Analogicznie: utożsamianie się z tym, co wypowiada autorytet, nie jest bynajmniej bezwolnym, bezkrytycznym uznaniem tego od razu za prawdę, ale wymaga często podjęcia „bolesnego” wysiłku wykroczenia poza siebie: zrozumienia tego, co zrazu w wypowiedziach innego/autorytetu wydaje się niezrozumiałe, obce, a niekiedy wręcz absurdalne, gdyż nie mieści się w horyzoncie własnego samorozumienia” (s. 330-331). Zdołaliśmy zatem jedynie zarysować to, jak Gadamer rozumie przesądy (przed-sądy), tradycję i autorytet. Nie pojmuje on ich bowiem tylko na sposób ontyczny, ale również ontologiczny. Dlatego możemy powiedzieć, że tradycja to „doskonały” autorytet. 
W jakim stopniu koncepcja Gadamera wpisuje się z koncepcją Heglowską - to istotne pytanie. Liczne nawiązania autora Prawdy i metody do twórczości Heideggera, są zdaniem Dybla próbą uwolnienia się od metafizycznego jej ujęcia, które zdaje się być charakterystyczne dla koncepcji Hegla. Dlatego też metafora „refleksu”, do której nawiązuje Frank, nie wyczerpuje tego, co miał do powiedzenia Gadamer, co do „rzeczy tradycji” (s. 357-361). Podobnego uproszczenia niemiecki uczony dokonuje względem opisu relacji rozumienia i „samorozumienia”. Co więcej, równie nietrafioną tezą jest ta, głoszona przez Franka, jakoby pojęcie dziejowej tradycji pełniło funkcję podmiotu. Nie ma mowy o żadnej „podstawie-podmiocie”: „Słowem, rozumienie „jest” rozumieniem jedynie o tyle, o ile jest już zawsze poza sobą, o ile w swym ,jednoczącym" odniesieniu do rzeczy, która ma w nim zostać zrozumiana, wykracza już poza siebie ku nieskończenie innym możliwościom jej rozumienia (s. 366). Heidegger kładł nacisk na „bycie tu oto”, zaś tradycja była o tyle istotna, o ile w odpowiedniej mierze dochodziła w niej do głosu „prawda” owego „bycia”. Jeszcze inaczej mówiąc: Heidegger stawiał pytania tradycji, Gadamer z kolei starał się odpowiedzieć na „zagadnięcia” przez tradycję. Kładł przez to większy nacisk na to, co przeszłe. Co więcej, zdaniem autora omawianej monografii należy przyjrzeć się neoplatońskiemu modelowi relacji pomiędzy bytem a źródłem. Dzięki temu ujęciu zaczerpniętym również z heideggerowskiej koncepcji dziejowości bycia, zostaje przełamana transcendentalna, jak gdyby niezmienna i stała, aprioryczna struktura rozumienia dziejowego. Platońska emanacja, a szczególnie rozumienie Dasein przez autora Bycia i czasu stają się dla Gadamera głównymi „przesłankami”, aby proces dziejowego rozumienia, a zarazem relacji ontycznego i ontologicznego wymiaru tradycji, nadać (jak i samorozumieniu) bardzo dynamiczny, ciągły, „samoróżnicujący się" charakter. Dlatego też w przeciwieństwie do Habermasa nie należy uważać Gadamera za konserwatystę. O koncepcji Gadamera można powiedzieć, że wykracza ona poza ontologiczne schematy metafizycznej tradycji. Ujmuje relację między tym, co uniwersalne a tym, co partykularne.

Czy od metafizyki można uciec? Zdaniem Heideggera i Derridy nie jest to możliwe. Nie należy jej zwalczać, przezwyciężać. Starajmy się ją rozpoznać, ale nie sytuując „siebie” w centrum, lecz na samych jej obrzeżach. Tak aby poznać jej granice (niedoskonałości i słabości), aby zupełnie inaczej, jak do tej pory do niej się ustosunkować, nie ograniczając się przy tym tylko i wyłącznie do zmiany znaczeń pojęć, jakimi w jej obrębie najczęściej się posługujemy. Tego rodzaju dyskurs, charakterystyczny dla Derridy i innych starających się „zwinąć” metafizykę: „[...] nie ma ściśle biorąc żadnego „miejsca”, które 
można byłoby w nim zidentyfikować, jako to „skąd” jest wypowiadany, które byłoby - w tym sensie - jego podstawą czy źródłem. Jest on z założenia atopiczny (atonon)" (s. 423-424). Co, zdaniem Gadamera, sprzyja prowadzeniu dialogu $\mathrm{z}$ tradycją (autorytetem).

Ta postawa w dyskusji filozoficznej z Derridą stała się jednak „kością niezgody”. Kluczowe dla obu myślicieli jest zagadnienie, czy „moment różnicy” jest „pierwszy” przed „momentem tożsamości”. W pewnym sensie jest to pytanie typu, co było pierwsze, jajko czy kura? Niemniej jednak jest ono ważne, szczególnie w sytuacji, w której obaj dostrzegają różnicę pomiędzy „rozumieniem czegoś” a „rozumieniem siebie” - w zderzeniu z „innobytem” (Hegel). Zdaniem Dybla powyższe uproszczenie jest nietrafne, nie oddaje ono Derridowskiej difference, albowiem „różnicowanie się różnicy” przebiega na innym „pre-ontologicznym” poziomie. Uwidacznia się jak gdyby w języku, a dokładniej rzecz ujmując - w jego zapisie. Dlatego tożsamość i „rozumienie czegoś" Derrida traktuje zasadniczo jako niewspółmierne, w przeciwieństwie do autora Prawdy i metody, dla którego oba te momenty współgrają ze sobą, na rzecz ciągłości rozumienia dziejowego.

Niezależnie od różnic i punktów wspólnych u Gadamera i Derridy należy podkreślić, że hermeneutyka filozoficzna dzięki m.in. Gadamerowi, ale i jego adwersarzom, nadała bieg innym, nowym badaniom w obrębie nauk humanistycznych. Książka Pawła Dybla jest tego dowodem. Z jednej strony w rzetelny sposób rekonstruuje ona poglądy niemieckiego uczonego, z drugiej zaś w bardzo przystępny i przejrzysty sposób stara się ukazać liczne niespójności, pęknięcia w tej niezwykle szerokiej perspektywie uprawiania filozofii. Podzielam zdanie autora, że zarysowana postawa badacza (humanisty) jest wartościowa. Słuszne jest nastawienie na zrozumienie innego $\mathrm{z}$ jednoczesnym dążeniem do porozumienia z nim. Równie istotny jest tak właśnie zarysowany przez niemieckiego hermeneutę stosunek do tradycji i autorytetu. Granice rozumienia i interpretacji. O hermeneutyce Hansa-Georga Gadamera, to opracowanie, w którym bardzo szczegółowo i celnie zaprezentowano znaczenie poruszanych przez Gadamera zagadnień. Niewątpliwie jest to książka warta uwagi i polecenia.

Jakub Maciejewski 